
УДК 615.015:616.001.8

DOI 10.11603/1811-2471.2019.v0.i2.10381

\title{
КІНЕТИКА АБСОРБЦІї НОВОГО АНТИГІПОКСАНТА ОКАГЕРМ-4 У НОРМІ ТА ЗА УМОВ ГІПОКСІЙНОГО СИНДРОМУ
}

\author{
๑Д. Ф. Літвіненко, В. Д. Лук'янчук \\ ДУ «Інститут фармакології та токсикології НАМн України», Київ
}

РЕЗюмЕ. Актуальною проблемою фармакології $€$ пошук високоефективних та безпечних засобів фармакотерапії гострої гіпоксії, що розвивається у замкнутому невентильованому просторі й називається гіпоксією замкнутого простору (ГЗП). На сьогодні у цьому сенсі перспективними вважають координаційні сполуки германію (КСГ) з такими біологічно активними лігандами як мікроелементи та органічні кислоти. Раніше проведеними скринінговими та токсикометричними дослідженнями виявлена висока антигіпоксійна активність та безпечність уперше синтезованої КГС - манган(II) тартратогерманат(IV), під лабораторним шифром ОКАГЕРМ-4.

Мета - порівняльний фармакокінетичний аналіз потенційного антигіпоксанта ОКАГЕРМ-4 на етапі його абсорбції в нормі та на моделі ГзП.

Матеріал і методи. Досліди виконані на 48 нелінійних білих щурах обох статей масою 170-200 г, яких було поділено на дві групи. Перша група була контрольною, а у тварин другої групи моделювали ГзП шляхом розміщення тварин на 25 хв у ізольованих гермооб'ємах (10 дм³). Для визначення фармакокінетичного профілю через 45 хв; 3; 6 та 24 год (від моменту внутрішньочеревинного введення) у сироватці крові визначали рівень ОКАГЕРМ-4 за германієм колориметричним методом. Показники процесу абсорбції обчислювали в програмі Phoenix WinNonLin 8.1.

Результати. Для ОКАГЕРМ-4 у дозі 96,8 мг/кг побудовані фармакокінетичні криві. У рамках двокамерного аналізу динаміки концентрацій отримані наступні значення фармакокінетичних параметрів абсорбції ОКАГЕРМ-4:

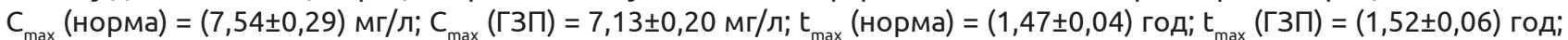
$\mathrm{K}_{01}^{\max }($ норма $)=(0,82 \pm 0,05)$ год ${ }^{-1} ; \mathrm{K}_{01}\left(\ulcorner З П)=(0,80 \pm 0,05)\right.$ год ${ }^{-1} ; \mathrm{t}_{1 / 2 a}($ норма $)=(0,85 \pm 0,07)$ год; $\mathrm{t}_{1 / 2 a}(\ulcorner 3 П)=(0,87 \pm 0,05)$ год.

Висновки. Експериментально встановлено, що за умов ГЗП відбуваються суттєві зміни параметра $C_{\text {max }}$.

КЛючОВІ СЛОВА: фармакокінетика; абсорбція; ОКАГЕРМ-4; гіпоксія замкнутого простору.

Вступ. Фармакотерапія гіпоксійних станів $\epsilon$ надзвичайно важливою проблемою для науки в цілому і для практичної медицини зокрема. Однією з найнебезпечніших форм екзогенної гіпоксії $\epsilon$ прогресуюча гіпоксія у поєднанні з гіперкапнією, що виникає при низькому парціальному тиску кисню та високій концентрації діоксиду вуглецю у повітрі, що вдихається. Така гіпоксія розвивається, як правило, у замкнутому невентильованому просторі й більше відома як гіпоксія замкнутого простору (ГЗП). Вона миттєво формується за умов різних екстремальних ситуацій, коли порушується штатна робота системи киснезабезпечення в герметичному об'єкті, де вміст кисню стрімко знижується, а концентрація вуглекислого газу - збільшується [1-4].

Попри те, що сучасна фармацевтична індустрія пропонує широкий вибір лікарських засобів, які мають властивості антигіпоксантів, пошук високоефективних та безпечних антигіпоксантів, як і раніше, триває, оскільки наразі в реєстрі лікарських засобів відсутні такі, що здатні істотним чином коригувати наслідки впливу гострого гіпоксійного синдрому, що сформувався саме в замкнутому просторі [5].

В останнє десятиріччя особлива увага фармакологів та хіміків-синтетиків зосереджена на всебічному вивченні в якості потенційних антигіпоксантів координаційних сполук германію з біолі- гандами, що відрізняються різноманітністю фармакодинамічних ефектів, прийнятним фармакокінетичним профілем та відносною нешкідливістю, синтез яких здійснений на кафедрі загальної хімії та полімерів Одеського державного університету імені І. І. Мечникова під керівництвом проф. І. Й. Сейфулліної [6-11].

Серед перспективних уперше синтезованих координаційних сполук германію особливий інтерес викликає манган(II) тартратогерманат(IV) під лабораторним шифром ОКАГЕРМ-4, високу антигіпоксичну активність якої на моделі ГЗП [12] та нешкідливість [13] було експериментально доведено.

Як відомо, на доклінічному етапі вивчення потенційного лікарського засобу обов'язковим етапом $\epsilon$ визначення його фармакокінетичного профілю, зокрема початкової ланки кінетики в організмі- абсорбції.

Мета - провести порівняльний фармакокінетичний аналіз потенційного антигіпоксанта ОКАГЕРМ-4 на етапі його абсорбції в нормі та на моделі ГЗП.

Матеріал і методи дослідження. Досліди виконані на 48 нелінійних білих щурах обох статей масою 170-200 г у відділі фармакокінетики ДУ «Інститут фармакології та токсикології НАМН України» відповідно до методичних рекомендацій [14], з дотриманням етичних вимог згідно з положеннями «Європейської конвенції по захисту хребетних 
Огляди літератури, оригінальні дослідження, погляд на проблему, випадок з практики, короткі повідомлення тварин, яких використовують для експериментальних та наукових цілей» [15] та чинного законодавства $[16,17]$.

Експериментальних тварин було розподілено на дві групи: щури без патології (норма) і дослідні тварини (ГЗП). Щурам обох груп ОКАГЕРМ-4 вводили одноразово внутрішньоочеревинно в оптимальній дозі 96,8 мг/кг, визначеній в попередньому фармакометричному експерименті [18]. ГЗП моделювали шляхом розміщення тварин на 25 хв в ізольованих гермооб'ємах (10 дм³), які перевертали до верху дном та поміщали в ємність 3 водою, щоб у такий спосіб запобігти потраплянню в них повітря.

Забір біоматеріалу для визначення фармакокінетичного профілю ОКАГЕРМ-4 здійснювали в динаміці: через 45 хв; 3; 6 та 24 години з моменту одноразового внутрішньочеревинного введення. Кількісне визначення ОКАГЕРМ-4 у крові проведено в біоаналітичній лабораторії клініко-діагностичного центру «Фармбіотест» (м. Рубіжне). При цьому використовували валідований метод кількісного визначення германію в біологічній матриці зі спектрофотометричним детектуванням за методом В. Й. Кресюна та співавт. [19].

Визначали низку фармакокінетичних показників, що характеризують процес абсорбції, а саме: константу швидкості абсорбції $\left(\mathrm{K}_{01}\right)$, період напівабсорбції ( $\left.t_{1 / 2, a}\right)$, максимальну концентрацію препарату в крові ( $\left.C_{\text {max }}\right)$, час досягнення максимальної концентрації в крові $\left(t_{\max }\right)$. Усі кінетичні параметри обчислювали за допомогою комп'ютерної програми Phoenix WinNonLin 8.1 (Pharsight Corp., Certara L.P., CША) [20] з використанням двокомпартментної моделі $[21,22]$, яка, як відомо, $\epsilon$ найоптимальнішою для вирішення такого роду задач.

Оскільки, згідно з критерієм перевірки нормальності розподілу Шапіро-Уілка, всі наведені параметри підпорядковуються нормальному закону розподілу, для порівняння був використаний t-критерій Стьюдента. Аналіз даних виконано в програмі StatSoft Statistica 10.

Результати й обговорення. На підставі отриманих фармакокінетичних кривих, що представлені на рисунку 1, безпосередньо були виконані розрахунки низки фармакокінетичних параметрів, які наведені в таблиці 1, що характеризують процес абсорбції ОКАГЕРМ-4 в організмі щурів без патології та тих, що зазнали впливу ГЗП.

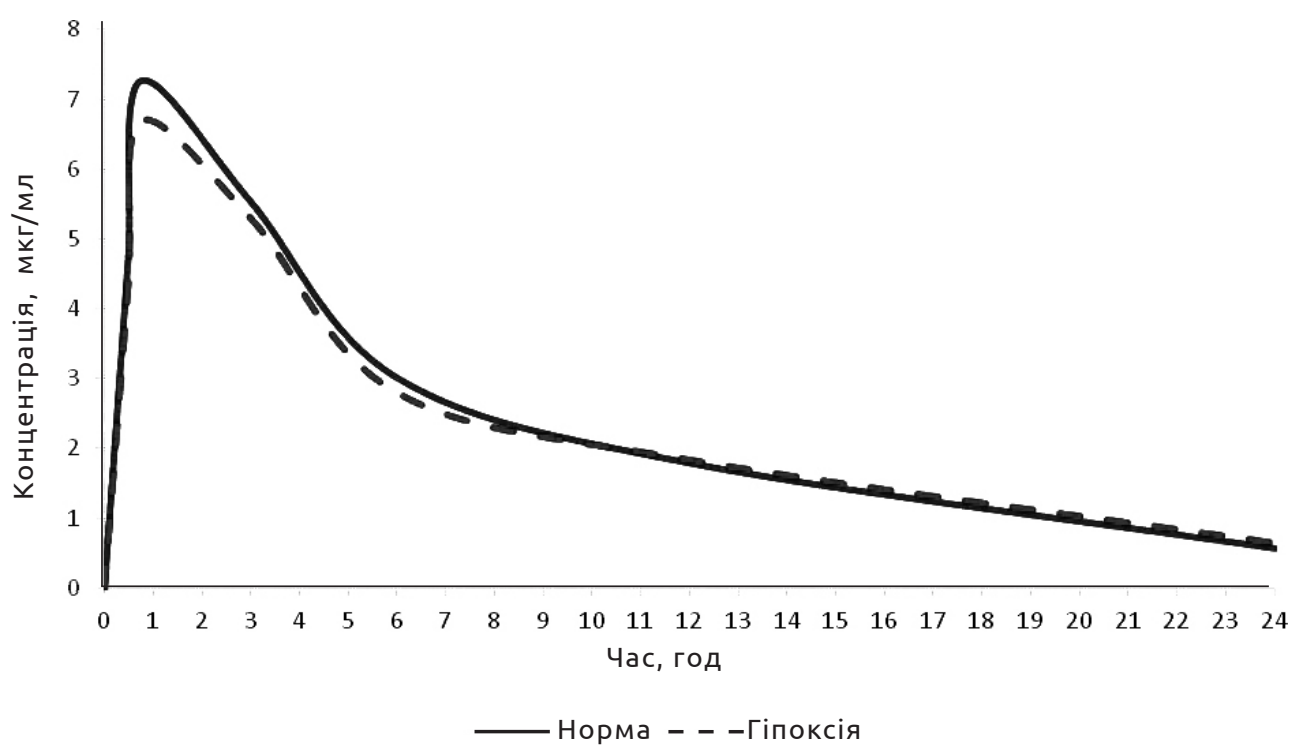

Рис. 1. Фармакокінетика ОКАГЕРМ-4 у лінійних координатах у крові в нормі та в умовах гіпоксії замкнутого простору при його внутрішньоочеревинному введенні в дозі 96,8 мг/кг.

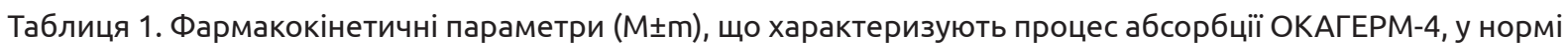
та в умовах гіпоксії замкнутого простору при внутрішньоочеревинному введенні в дозі 96,8 мг/кг $(n=6)$

\begin{tabular}{|c|c|c|c|c|}
\hline \multirow{2}{*}{ Параметр } & \multirow{2}{*}{ Позначення, розмірність } & \multicolumn{2}{|c|}{ Група тварин } & \multirow{2}{*}{$\mathrm{P}$} \\
\hline & & норма & гіпоксія & \\
\hline Константа швидкості абсорбції & $\mathrm{K}_{01}$, год $^{-1}$ & $0,82 \pm 0,05$ & $0,80 \pm 0,05$ & $>0,05$ \\
\hline Період напівабсорбції & $\mathrm{t}_{1 / 2 a^{\prime}}$ год & $0,85 \pm 0,07$ & $0,87 \pm 0,05$ & $>0,05$ \\
\hline Час досягнення максимальної концентрації & $\mathrm{t}_{\text {max }}$ год & $1,47 \pm 0,04$ & $1,52 \pm 0,06$ & $>0,05$ \\
\hline Максимальна концентрація & $\mathrm{C}_{\max }, \mathrm{Mr} / л$ & $7,54 \pm 0,29$ & $7,13 \pm 0,20$ & $<0,05$ \\
\hline
\end{tabular}

Примітка. Р-у порівнянні із здоровими тваринами (норма). 
Огляди літератури, оригінальні дослідження, погляд на проблему, випадок з практики, короткі повідомлення

Аналіз швидкості всмоктування сполуки, що вивчається, у системний кровообіг, свідчить про достатньо високу інтенсивність цього процесу як в нормі, так і за умов гіпоксійного ураження, попри те, що ОКАГЕРМ-4 має велику молекулярну масу та просторову структуру. На це вказують доволі високі значення констант швидкостей абсорбції в обох групах. Величина $\mathrm{K}_{01}$ в групах тварин, що вивчаються, приблизно однакова і стано-

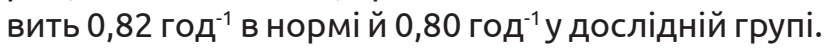

Висока швидкість абсорбції обумовлена, на нашу думку, низкою факторів. Значну роль відіграє внутрішньоочеревинний шлях введення щурам потенційного антигіпоксанта. Такий шлях застосування ОКАГЕРМ-4 був обраний з огляду на те, що у щурів абсорбційний період при внутрішньоочеревинному введенні, для більшості речовин, на 25-50 \% більший, аніж при внутрішньовенній інфузії, й у плазмі крові досягаються концентрації, близькі до таких, що спостерігаються саме при внутрішньовенному введенні [23]. Це максимально наближає експериментальну модель фармакотерапії гіпоксійної травми до умов клінічного застосування препарату, тому що внутрішньовенний шлях $є$ найоптимальнішим в при наданні екстреної допомоги постраждалим [24].

Слід наголосити на тому, що висока абсорбційна здатність очеревини зумовлена ії морфофункціональними особливостями. Очеревина $\epsilon$ напівпроникною діалізуючою мембраною, через яку в обох напрямках (в черевну порожнину і з неї до загального кровотоку) переміщуються вода, електроліти, низькомолекулярні субстанції [25]. Крім того, вона має велику площу поверхні та ін-

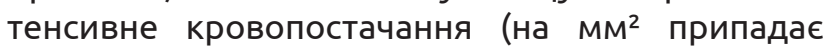
75000 капілярів) [26]. Отже, у щурів за умов інтраперитонеальної аплікації, завдяки одношаровому мезотелію очеревини відбувається вельми швидке всмоктування хімічних сполук будь-якої будови, в тому числі координаційних.

Отримані в експерименті дані свідчать, що процес абсорбції ОКАГЕРМ-4 є достатньо інтенсивним, як у нормі, так і за умов такого енергодефіцитного стану як ГЗП. При цьому за умов гіпоксійного синдрому обов'язково виникають порушення енергозабезпечення транспортних механізмів. Відомо, що порушення мембранного транспорту за умов гіпоксії відбувається внаслідок роз'єднання процесів окиснення та фосфорилювання, що, певна річ, викликає дисбаланс у системі аденілових нуклеотидів і призводить до зниження швидкості аеробного окиснення субстратів та порушення функціонування всіх АТФзалежних ферментних комплексів, що беруть безпосередню участь у реалізації мембранотранспортних механізмів [27].
Висока інтенсивність абсорбції та відсутність значної різниці в показниках $\mathrm{K}_{01}$ у нормі та за умов ГЗП, на нашу думку, може бути свідченням того, що всмоктування ОКАГЕРМ-4 відбувається шляхом пасивної дифузії за градієнтом концентрації 3 мінімальними енергетичними витратами, шляхом розчинення сполуки в ліпідній фазі мембрани $[28,29]$. Висока розчинність ОКАГЕРМ-4 у ліпідах обумовлена наявністю в складі координаційної сполуки аніонів винної кислоти, що й визначає фізико-хімічні властивості сполуки та особливості ії̈ мембранного транспорту [30].

Фармакокінетичні показники, що характеризують абсорбцію, крім шляху введення і фізико-хімічних властивостей препарату, значною мірою залежать від стану центральної гемодинаміки та реґіонарного кровотоку. Тому відсутність різниці в величинах констант швидкості абсорбції в досліджуваних групах обумовлена, найімовірніше, розвитком у початковому періоді гіпоксійної травми, який у часі збігається з періодом абсорбції ОКАГЕРМ-4, та екстремальним станом захисно-адаптивних реакцій з боку серцево-судинної системи. Вже з перших хвилин розвитку гострої гіперкапнічної гіпоксії відбувається активація симпатоадреналової системи з викидом катехоламінів, накопичення в міокарді метаболітів з вазодилатаційним ефектом (аденозин, кініни, простагландин Е тощо), що призводить до збільшення ударного об'єму i хвилинного об'єму серця, а значить і швидкості кровотоку, внаслідок чого показники макро- і мікрогемодинаміки та $\mathrm{K}_{01}$ у тварин у групі ГЗП не відрізняються від контрольної групи [31].

Порівняльна оцінка такого показника кінетики як період навпівабсорбції $\left(t_{1 / 2 a}\right)$ ОКАГЕРМ-4, який тісно пов'язаний з константою швидкості абсорбції $\left(\mathrm{K}_{01}\right)$ обернено пропорційною залежністю, свідчить про відсутність значної різниці в рівнях величин $t_{1 / 2 a}$ в обох групах (в нормі 0,85 год $\mathrm{i}$ 0,87 год в дослідній). Отже, швидкість і час проникнення ОКАГЕРМ-4 з черевної порожнини у кров, як взаємопов'язані параметри, статистично не відрізняються між собою, пояснення чого було наведено вище.

Порівняльний аналіз наступного фармакокінетичного показника - часу досягнення максимальної концентрації ( $C_{\text {max }}$ ) ОКАГЕРМ-4 - свідчить про швидкість реалізації фармакологічного ефекту. Важливо зазначити, що в групі тварин з ГЗП пік концентрації ОКГЕРМ-4 в крові менший $(P<0,05)$, порівняно з групою тварин у нормальному стані: при ГЗП С ${ }_{\max }$ становить 7,13 мг/мл проти 7,54 мг/мл в нормі, що на 5,4 \% нижче. Цей факт можна пояснити тим, що в результаті феномену централізації кровообігу (перерозподілу кровотоку на користь серця, легень і мозку), який є одним із екс- 
Огляди літератури, оригінальні дослідження, погляд на проблему, випадок з практики, короткі повідомлення трених захисно-компенсаторних механізмів при гострій гіпоксії, відбувається значне зниження кровотоку в гепатоспланхнічному басейні [3234], що сприяє зниженню швидкості абсорбції, а внаслідок цього й зменшенню величини параметра $C_{\max }$ у тварин дослідної групи.

При порівняльному аналізі фармакокінетичного параметра, який свідчить про час досягнення максимальної концентрації ( $\left.t_{\max }\right)$ ОКАГЕРМ-4, слід звернути увагу, що в обох групах цей параметр майже однаковий і дорівнює в середньому 1,5 год (див. табл.1). Це вказує на відсутність різниці у величинах латентного періоду протигіпоксійної активності сполуки, що вивчається, незалежно від умов, в яких вона застосовується, а саме в нормі, чи за умов ГЗП, що моделюються. Короткий латентний період пояснюється значною швидкістю абсорбції ОКАГЕРМ-4, яка обумовлена

вищеописаними фізико-хімічними властивостями потенційного антигіпоксанта та особливостями його трансмембранного транспорту.

Висновки. Провівши всебічний фармакокінетичний аналіз етапу абсорбції ОКАГЕРМ-4, у порівняльному аспекті, у нормі та при ГЗП, шляхом визначення комплексу параметрів, можна зробити висновок, що у тварин, котрі зазнали впливу гострої гіпоксії з гіперкапнією, має місце вірогідне $(\mathrm{P}<0,05)$ зниження величини параметра $C_{\max }$. Це пов'язано з неминучими змінами системної гемодинаміки й мікроциркуляції при гіпоксійному синдромі будь-якої етіології. Цей факт може позначитися на ступені реалізації протигіпоксійної дії потенційного антигіпоксанта, що буде вимагати подальшого корегування режиму дозування ОКАГЕРМ-4 за умов його клінічного застосування.

\section{ЛІТЕРАТУРА}

1. Метаболические корректоры гипоксии /П. Д. Шабанов, И. В. Зарубина, В. Е. Новиков, В. Н. Цыган - СПб. : ИнформНовигатор, 2010. - 912 с.

2. Pittman R. N. Regulation of Tissue Oxygenation / R. N. Pittman // Colloquium: Series on Integrated Systems Physiology: From Molecule to Function - 2011. - Vol. 3, No. 3. - P. 1-100.

3. Katschinski D. M. Editorial: an introduction and welcome to hypoxia / D. M. Katschinski // Hypoxia. - 2013. No. 1. - P. 29-30.

4. Wenger R. H. Frequently asked questions in hypoxia research / R. H. Wenger, V. Kurtcuoglu, C. C. Scholz // Hypoxia. -2015 - No. 3. - P. 35-43.

5. Лукьянова Л. Д. Новое о сигнальных механизмах адаптации к гипоксии и их роли в системной регуляции / Л. Д. Лукьянова, Ю. И. Кирова, Г. В. Сукоян // Патогенез. - 2011. - Т. 9, № 3. - С. 4-14.

6. Лук'янчук В. Д. Порівняльні скринінгові дослідження в ряду координаційних сполук германію на моделі гіпоксії замкнутого простору / В. Д. Лук'янчук, І. Й. Сейфулліна, К. О. Шебалдова // Український журнал екстремальної медицини ім. Г. О. Можаєва. - 2013. № 1. - С. 81-84.

7. Координаційні сполуки германію - стратегічний вектор пошуку антигіпоксантів / В. Д. Лук'янчук, І. Й. Сейфулліна, І. О. Житіна [та ін.] // XII 3'їзд всеукраїнського лікарського товариства (ВУЛТ) 5-7 вересня 2013: тез. доп. - Київ, 2013. - С. 273.

8. Скринінг і порівняльна оцінка протиішемічної ефективності серед координаційних сполук германію при гострій цереброваскулярній недостатності / В. Д. Лук'янчук, І. О. Житіна, І. Й. Сейфулліна [та ін.] // Фармакологія та лікарська токсикологія. - 2010. № 1-2 (14-15). - С. 61-64.

9. Порівняльна протигіпоксична активність координаційних сполук германію / В. Д. Лук'янчук, А. А. Шутка, І. Й. Сейфулліна [та ін.] // Одеський медичний журнал. - 2010. - № 2. - С. 11-14.

10. Лучишин Т. Р. Пошук засобів фармакотерапії синдрому ендогенної інтоксикації серед координаційних сполук германію : автореф. дис. на здобуття наук, ступеня канд. мед. наук : спец. 14.03.05 «Фармакологія» / Т. Р. Лучишин. - Одеса, 2013. - 22 с.

11. Поліщук $€$. М. Експериментальне обґрунтування доцільності застосування нової координаційної сполуки Цереброгерм для лікування травматичного пошкодження головного мозку : автореф. дис. на здобуття наук. ступеня канд. мед. наук: спец. 14.03.05 «Фармакологія» / Є. М. Поліщук. - Одеса, 2015. - 20 с.

12. Літвіненко Д. Ф. Пошук потенційних антигіпоксантів серед оригінальних гетерометалічних комплексів германію та 3d-металів на основі лимонної та винної кислот / Д. Ф. Літвіненко, В. А. Козир, О. Е. Марцинко // Фармакологія та лікарська токсикологія. 2016. - № 6 (51). - С. 60-65.

13. Лукьянчук В. Д. Токсикометрический анализ нового антигипоксанта ОКАГЕРМ-4 / В. Д. Лукьянчук, Д. Ф. Литвиненко // Problems of biology and medicine. 2017. - № 3 (96). - С. 162-165.

14. Пошук та експериментальне вивчення потенційних протигіпоксійних засобів : методичні рекомендації / [В. Д. Лук'янчук, Л. В. Савченкова, О. Д. Немятих, В. М. Радіонов]. - К. : ДФЦ МОЗ України, 2002. - 27 с.

15. Європейська конвенція про захист хребетних тварин від 1986 р. [Електронний ресурс]. - Режим доступу: https://zakon5.rada.gov.ua/laws/show/994_137.4 (дата звернення: 21.02.2019).

16. Порядок проведення науковими установами дослідів, експериментів на тваринах : Наказ Міністерства освіти і науки, молоді та спорту України від 1 березня 2012 р. № 249 [Електронний ресурс]. - Режим доступу: https://zakon.rada.gov.ua/laws/show/z0416-12 (дата звернення: 21.02.2019).

17. Про затвердження Порядку проведення доклінічного вивчення лікарських засобів та експертизи матеріалів доклінічного вивчення лікарських засобів: На- 
Огляди літератури, оригінальні дослідження, погляд на проблему, випадок з практики, короткі повідомлення каз Міністерства охорони здоров'я України від 14 грудня 2009 р. № 944 [Електронний ресурс]. - Режим доступу: https://zakon5.rada.gov.ua/laws/show/z0053-10 (дата звернення: 21.02.2019).

18. Lukyanchuk V. Study of pharmacometric indexes of dosing regimen of antihypoxant OKAGERM-4 / V. Lukyanchuk, D. Kravets, D. Litvinenko // Georgian Medical News. - 2017. - Vol. 272, No. 11. - P. 144-147.

19. Кресюн В. Й., Щербаков С. В., Відавська А. Г. [та ін.]. Спосіб визначення мікрокількостей германію в тканинах тварин: Деклараційний патент на винахід, Україна, 2001. - № 38285. - Опубл. 15.05.2001. Бюл. № 4.

20. Phoenix 8.1. Phoenix PK/PD Modeling and Simulation Software [Electronic resource]. - Access mode : www. certara.com/software/ (дата звернення: 21.01.2019).

21. Sara E. Rosenbaum. Basic pharmacokinetics and pharmacodynamics: An integrated textbook and computer simulations / Sara E. Rosenbaum. - Hoboken, NJ: John Wiley \& Sons, Inc.; 2011. -430 p.

22. Андрущак I. Є. Моделі та методи оптимізації в програмному середовищі підтримки фармакокінетичних системних досліджень: [монографія] / І. Є. Андрущак. - Луцьк : РВВ Луц. НТУ, 2014. - 179 с.

23. Возможные пути и объемы введения лекарственных средств лабораторным животным / И. Е. Макаренко, О. И. Авдеева, Г.В.Ванатиев [та ін.] // Международный вестник ветеринарии. -2013. - № 3. - С. 8-84.

24. Адамс X-А. Атлас по неотложной помощи / Ханс-Антон Адамс, Андреас Флемминг, Ларс Фридрих, Хайнер Рушулте ; пер. с нем. - М. : МЕДпресс-информ, 2009. - 216 с.: ил.

25. Blackburn S. C. Anatomy and physiology of the peritoneum / S. C. Blackburn, M. P. Stanton // Semin. Pediatr. Surg. - 2014. - No. 23 (6). - P. 326-330.

\section{REFERENCES}

1. Shabanov, P.D., Zarubina, I.V., Novikov, V.Ye., \& Tsygan, V.N. (2010). Metabolicheskiye korrektory gipoksii [Metabolic correctors of hypoxia]. Saint-Petersburg: InformNovigator [in Russian].

2. Pittman, R.N. (2011). Regulation of tissue oxygenation. Colloquium: Series on Integrated Systems Physiology: From Molecule to Function, 3, 3, 1-100.

3. Katschinski, D.M. (2013). Editorial: an introduction and welcome to Hypoxia. Hypoxia, 1, 29-30.

4. Wenger, R.H., Kurtcuoglu, V., \& Scholz, C.C. (2015). Frequently asked questions in hypoxia research. Hypoxia, 3, 35-43.

5. Lukyanova, L.D., Kirova, Yu.I., \& Sukoyan, G.V. (2011). Novoye o signalnykh mekhanizmakh adaptatsii k gipoksii i ikh roli v sistemnoy regulyatsii [New about signaling mechanisms of adaptation to hypoxia and their role in systemic regulation]. Patogenez - Pathogenesis, 9, 3, 4-14 [in Russian].

6. Lukianchuk, V.D., Seyfullina, I.Y., \& Shebaldova, K.O. (2013). Porivnialni skryninhovi doslidzhennia v riadu koordynatsiinykh spoluk hermaniiu na modeli hipoksii zamknutoho prostoru [Comparative screening studies in the range of coordination compounds of germanium on the model of closed space hypoxia]. Ukrainskyi zhurnal ekstremalnoi

medytsyny im. H.O. Mozhaieva - Ukrainian Journal of Extreme Medicine named after H.O. Mozhaieva, 1, 81-84 [in Ukrainian].

7. Lukianchuk, V.D., Seifullina, I.Yu., \& Zhytina, I.O. (2013). Koordynatsiini spoluky hermaniiu - stratehichnyi vektor poshuku antyhipoksantiv [Coordination compounds of germanium - a strategic vector for the search for antihypoxants]. XII Zizd vseukrainskoho likarskoho tovarystva (VULT) 5-7 veresnia: tez. dop. - XII Congress of All-Ukrainian Medical Society (VULT) 5-7 September 2013: Abstracts of Papers. Kyiv [in Ukrainian].

8. Lukianchuk, V.D., Zhytina, I.O., \& Seifullina, I.Y. (2010). Skryninh i porivnialna otsinka protyishemichnoi efektyvnosti sered koordynatsiinykh spoluk hermaniiu pry hostrii tserebrovaskuliarnii nedostatnosti [Screening and comparative estimation of anti-ischemic efficacy among coordination compounds of germanium in acute cerebrovascular failure]. Farmakolohiia ta likarska toksykolohiia Pharmacology and Drug Toxicology, 1-2 (14-15), 61-64 [in Ukrainian].

9. Lukianchuk, V.D., Shutka, A.A., \& Seifullina, I.Y. (2010). Porivnialna protyhipoksychna aktyvnist koordynatsiinykh spoluk hermaniiu [Comparative antihypoxic activi- 
Огляди літератури, оригінальні дослідження, погляд на проблему, випадок з практики, короткі повідомлення ty of coordination compounds of germanium]. Odeskyi medychnyi zhurnal - Odesa Medical Journal, 2, 11-14 [in Ukrainian].

10. Luchyshyn, T.R. (2013). Poshuk zasobiv farmakoterapii syndromu endohennoi intoksykatsii sered koordynatsiinykh spoluk hermaniiu [The search for means of pharmacotherapy of endogenous intoxication syndrome among coordination compounds of Germanium]. Extended abstract of Candidate's thesis. Odesa [in Ukrainian].

11. Polishchuk, Ye.M. (2015). Eksperymentalne obhruntuvannia dotsilnosti zastosuvannia novoi koordynatsiinoi spoluky Tserebroherm dlia likuvannia travmatychnoho poshkodzhennia holovnoho mozku [Experimental substantiation of expediency of application of the new coordination compound Cerebrogerm for the treatment of traumatic brain damage]. Extended abstract of Candidate's thesis. Odesa [in Ukrainian].

12. Litvinenko, D.F., Kozyr, V.A., \& Martsynko, O.E. (2016). Poshuk potentsiinykh antyhipoksantiv sered oryhinalnykh heterometalichnykh kompleksiv hermaniiu ta 3d-metaliv na osnovi lymonnoi ta vynnoi kyslot [The search for potential antihypoxants among the original heteronomal complexes of germanium and $3 \mathrm{~d}$ metals on the basis of citric and tartaric acid]. Farmakolohiia ta likarska toksykolohiia - Pharmacology and Drug Toxicology, 6 (51), 60-65 [in Ukrainian].

13. Lukyanchuk, V.D., \& Litvinenko, D.F. (2017). Toksikometricheskiy analiz novogo antigipoksanta OKAGERM-4 [Toxicometric analysis of the new antihypoxant OKAGERM-4]. Problemy biologii i meditsiny - Problems of Biology and Medicine, 3 (96), 162-165 [in Russian].

14. Lukianchuk, V.D., Savchenkova, L.V., Nemiatykh, O.D., \& Radionov, V.M. (2002). Poshuk ta eksperymentalne vyvchennia potentsiinykh protyhipoksiinykh zasobiv: metodychni rekomendatsii [Search and experimental study of potential antifungal drugs: methodical recommendations]. Kyiv: DFTS MOZ Ukrainy [in Ukrainian].

15. Yevropeiska konventsiia pro zakhyst khrebetnykh tvaryn vid 1986 r. [European Convention for the Protection of Vertebrates from 1986]. Retrieved from: https://zakon5. rada.gov.ua/laws/show/994_137.4.

16. Poriadok provedennia naukovymy ustanovamy doslidiv, eksperymentiv na tvarynakh: Nakaz Ministerstva osvity i nauky, molodi ta sportu Ukrainy vid 1 bereznia 2012 r. № 249 [The order of the scientific institutions of experiments, experiments on animals: Order of the Ministry of Education and Science, Youth and Sport of Ukraine, March 1, 2012 No. 249]. Retrieved from: https://zakon.rada.gov.ua/ laws/show/z0416-12.

17. Pro zatverdzhennia Poriadku provedennia doklinichnoho vyvchennia likarskykh zasobiv ta ekspertyzy materialiv doklinichnoho vyvchennia likarskykh zasobiv: Nakaz Ministerstva okhorony zdorovia Ukrainy vid 14 hrudnia 2009 r. № 944 [On Approval of the Procedure for Pre-Clinical Examination of Medicines and Examination of Materials for Preclinical Study of Medicines: Order of the Ministry of Health of Ukraine of December 14, 2009 No. 944]. Retrieved from: https://zakon5.rada.gov.ua/laws/show/z0053-10.

18. Lukyanchuk, V., Kravets, D., \& Litvinenko, D. (2017). Study of pharmacometric indexes of dosing regimen of antihypoxant OKAGERM-4. Georgian Medical News, 272, $11,144-147$.

19. Kresyun, V.Y., Shcherbakov, S.V., \& Vidavska, A.H. (2001). Sposib vyznachennia mikrokilkostei hermaniiu v tkanynakh tvaryn: Deklaratsiynyi patent na vynakhid, Ukraina, № 38285. Opubl. 15.05.2001. Byul. № 4. - Method of determining the microhardness of germanium in animal tissues: Declaration Patent for an invention, Ukraine, 2001. No. 38285. Published. May 15, 2001 Bull No. 4 [in Ukrainian].

20. Phoenix 8.1. Phoenix PK/PD Modeling and Simulation Software Retrieved from: www.certara.com/software.

21. Rosenbaum, S.E. (2011). Basic Pharmacokinetics and Pharmacodynamics: An Integrated Textbook and Computer Simulations. Hoboken, NJ: John Wiley \& Sons, Inc.

22. Andrushchak, I.Ye. (2014). Modeli ta metody optymizatsii $v$ prohramnomu seredovyshchi pidtrymky farmakokinetychnykh systemnykh doslidzhen: [monohrafiia] [Models and methods of optimization in the software environment supporting pharmacokinetic system research: [monograph]. Lutsk: RVV Luts. NTU [in Ukrainian].

23. Makarenko, I.Ye., Avdyeyeva, O.I., Vanatiyev, G.V., Rybakova, A.V., Khodko, S.V., Makarova, M.N., \& Makarov, V.G. (2013). Vozmozhnyye puti i obyemy vvedeniya lekarstvennykh sredstv laboratornym zhivotnym [Possible paths and volumes of administration of drugs to laboratory animals]. Mezhdunarodnyy vestnik veterinarii - International Journal of Veterinary Medicine, 3, 78-84 [in Russian].

24. Adams, Kh.A., Flemming, A., Fridrikh, L., Rushulte, Kh. (Eds.) (2009). Atlas po neotlozhnoy pomoshchi [Emergency Atlas]. Moscow: MEDpress-inform, [in Russian].

25. Blackburn, S.C., \& Stanton, M.P. (2014). Anatomy and physiology of the peritoneum. Semin. Pediatr. Surg., 23 (6), 326-330.

26. Guyton, A.C., \& Hall, J,E. (2016). Textbook of Medical Physiology. $13^{\text {th }}$ Edition. Philadelphia, PA: Elsevier Science.

27. Shebaldova, K.O. (2014). Eksperymentalne obhruntuvannia rozrobky zasobiv likarskoi profilaktyky hipoksii zamknutoho prostoru v riadu koordynatsiinykh spoluk hermaniiu [Experimental substantiation of development of means of medical prophylaxis of closed space hypoxia in a series of coordination compounds of germanium]. Candidate's thesis. Kyiv [in Ukrainian].

28. Seydel, J.K., \& Wiese, M. (2002). Drug-Membrane Interactions: Analysis, Modeling. Weinheim: Wiley-VCH Verlag GmbH\&Co. KGaA.

29. Sadovnichenko, Yu.A., \& Myasoyedov, V.V. (2015). Kletochnyye membrany. Transport veshchestv cherez plazmalemmu: Metod. rek. dlya samost. vneaud. raboty stud. [Cell membranes. Transport of substances through the plasma membrane: Method. recommendations for individual outclass work of students]. Kharkov: KHNMU [in Ukrainian].

30. Seyfullina, I.I., \& Martsinko, Ye.E. (2015). Koordinatsionnyye soyedineniya germaniya (IV) s anionami limonnoy, vinnoy i ksilarovoy kislot [Coordination compounds of germanium (IV) with anions of citric, tartaric and xylaric acids]. Odesa: Odesskiy natsionalnyy universitet imeni I. I. Mechnikova [in Russian].

31. Zoccal, D.B. (2015). Peripheral chemoreceptors and cardiorespiratory coupling: a link to sympathoexcitation. Experim. Physiol., 2 (100), 2143-2148.

32. Zilbernagl, S., \& Lang, F. (2015). Klinicheskaya patofiziologiya. Atlas. [Clinical pathophysiology. Atlas]. Moscow: Prakticheskaya meditsina [in Russian]. 
Огляди літератури, оригінальні дослідження, погляд на проблему, випадок з практики, короткі повідомлення

33. Litvitskiy, P.F. (2016). Gipoksiya [Hypoxia]. Voprosy sovremennoy pediatrii - Questions of Modern Pediatrics, 6, 1, 45-58 [in Russian].
34. Roach, R.C., Wagner, P.D., Hackett, P.H. (2007). Hypoxia and the Circulation. Springer Science+Business Media, LLC.

\title{
КИНЕТИКА АБСОРБЦИИ НОВОГО АНТИГИПОКСАНТА ОКАГЕРМ-4 В НОРМЕ И В УСЛОВИЯХ ГИПОКСИЧЕСКОГО СИНДРОМА
}

\author{
๑Д. Ф. Литвиненко, В. Д. Лукьянчук \\ ГУ «Институт фармакологии и токсикологии НАМН Украины», Киев
}

\begin{abstract}
РЕЗЮМЕ. Актуальной проблемой фармакологии является поиск высокоэффективных и безопасных средств фармакотерапии острой гипоксии, которая развивается в замкнутом невентилируемом пространстве, и имеет название гипоксия замкнутого пространства (ГЗП). На сегодня, в этом плане, перспективными кажутся координационные соединения германия (КСГ) с биологически активными лигандами в виде микроэлементов и органических кислот. Ранее проведёнными скрининговыми и токсикометрическими исследованиями обнаружена высокая антигипоксическая активность и безопасность впервые синтезированного КСГ - марганец(II) тартратогерманат (IV) под лабораторным шифром ОКАГЕРМ-4.

Цель - сравнительный фармакокинетический анализ потенциального антигипоксанта ОКАГЕРМ-4 на этапе его абсорбции в норме и на модели ГзП.

Материал и методы. Эксперименты выполнены на 48 нелинейных белых крысах обоих полов массой 170200 г, которые были распределены на две группы. Первая группа была контрольной, а у животных второй группы моделировали ГзП путем размещения животных на 25 мин в изолированных гермообъёмах (10 дм³). Для определения фармакокинетического профиля через 45 мин; 3; 6 и 24 ч (от момента внутрибрюшинного введения) в сыворотке крови определяли уровень ОКАГЕРМ-4 по германию колориметрическим методом. Показатели процесса абсорбции вычисляли в программе Phoenix WinNonLin 8.1.
\end{abstract}

Результаты. Для ОКАГЕРМ-4 в дозе 96.8 мг/кг построены фармакокинетические кривые. В рамках двухкамерного анализа динамики концентраций получены следующие значения фармакокинетических параметров (М $\pm m)$

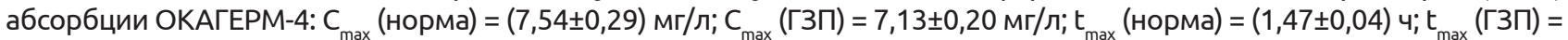
$(1,52 \pm 0,06) 4 ; K_{01}$ (норма) $=(0,82 \pm 0,05) 4^{-1} ; K_{01}(Г 3 П)=(0,80 \pm 0,05) 4^{-1} ; t_{1 / 2 a}\left(\right.$ норма) $=(0,85 \pm 0,07) 4 ; t_{1 / 2 a}(Г 3 \Pi)=(0,87 \pm 0,05) 4$.

Выводы. Экспериментально установлено, что в условиях ГЗП происходит существенное изменение параметра $C_{\text {max }}$.

КЛЮЧЕВЫЕ СЛОВА: фармакокинетика; абсорбция; ОКАГЕРМ-4; гипоксия замкнутого пространства.

\section{KINETICS OF ABSORPTION OF A NEW ANTIHYPOXYANT OKAGERM-4 IN NORM AND IN CONDITIONS OF HYPOXIC SYNDROME}

\author{
@D. F. Litvinenko, V. D. Lukyanchuk \\ Institute of Pharmacology and Toxicology, Kyiv
}

SUMMARY. The actual problem of pharmacology is the search for highly effective and safe means of pharmacotherapy for acute hypoxia, which develops in a closed unventilated space and is called confined space hypoxia. Today, in this regard, promising are the coordination compounds of germanium with biologically active ligands in the form of trace elements and organic acids. Previously conducted screening and toxicometric studies revealed a high antihypoxic activity and safety of the first synthesized coordination compound of germanium - manganese (II) tartratogermanat (IV) under the laboratory code OKAGERM-4.

The aim - comparative pharmacokinetic analysis of a potential antihypoxant OKAGERM-4 at the stage of its absorption in normal conditions and on a confined space hypoxia model.

Material and Methods. The experiments were performed on 48 white rats of both sexes weighing 170-200 g, which were divided into two groups. The group 1 was the control, and in animals of the groupn 2, confined space hypoxia was simulated by placing animals for $25 \mathrm{~min}$ in isolated sealed volume $\left(10 \mathrm{dm}^{3}\right)$. To determine the pharmacokinetic profile after 45 min; 3; 6 and $24 \mathrm{~h}$ (since intraperitoneal injection) in the serum was determined by the level of OKAGERM-4 by the colorimetric method. Indicators of the absorption process were calculated using the Phoenix WinNonLin 8.1 program.

Results. For OKAGERM-4 at a dose of $96.8 \mathrm{mg} / \mathrm{kg}$, pharmacokinetic curves were constructed. The following pharmacokinetic parameters $(\mathrm{M} \pm \mathrm{m})$ of the OKAGERM-4 absorption were obtained in a two-chamber analysis of concentration dynamics: $C_{\max }($ normal $)=(7.54 \pm 0.29) \mathrm{mg} / ; C_{\text {max }}$ (hypoxia) $=(7.13 \pm 0.20) \mathrm{mg} / \mathrm{l} ; \mathrm{t}_{\max }($ norm $)=(1.47 \pm 0.04) \mathrm{h} ; \mathrm{t}_{\max }$ (hypoxia) $=(1.52 \pm 0.06) \mathrm{h}$; $\mathrm{K}_{01}($ norm $)=(0.82 \pm 0.05) \mathrm{h}^{-1} ; \mathrm{K}_{01}($ hypoxia $)=(0.80 \pm 0.05) \mathrm{h}^{-1} ; \mathrm{t}_{1 / 2 \mathrm{a}}($ norm $)=(0.85 \pm 0.07) \mathrm{h} ; \mathrm{t}_{1 / 2 a}$ (hypoxia) $=(0.87 \pm 0.05) \mathrm{h}$.

Conclusions. It was established experimentally that under conditions of confined space hypoxia, a significant change in the $C_{\text {max }}$ parameter occurs.

KEY WORDS: pharmacokinetics; absorption; OKAGERM-4; confined space hypoxia. 